\title{
Virtual Chinese Literature: A Comparative Case Study of Online Poetry Communities*
}

\author{
Michel Hockx
}

\begin{abstract}
This article looks at the practices of communities that employ internet technologies in order to produce, distribute, consume and value Chinese poetry. The article is in three parts. The first part provides a brief general overview of the current state of research about the Chinese internet. I take issue with the dominant tendency of English-language research to focus almost exclusively on questions of censorship. The second part looks at the development of "web literature" (wangluo wenxue) in China, briefly outlining the meaning of the term and the content of a protracted debate about web literature that took place in 2001. The debate illustrates the limited extent to which web literature is able to distinguish itself from conventionally published literature. Paradoxically, this has led to "web literature" becoming a recognized genre within print culture. In the final part, I compare a PRC online poetry community with a similar community based in the USA. I conclude by arguing that previous scholarship's biased focus on the transformative aspects of cyber culture has made it difficult to gain a clear insight into the many positive and culture-specific features of Chinese web literature.
\end{abstract}

Discussing the distinction between web literature and literature is as boring as discussing the distinction between web love and traditional love. --.-.wwwmm"1

According to statistics from the China Internet Network Information Center (CNNIC) there were by the end of 2004 approximately 668,900 websites on the Chinese world-wide web. ${ }^{2}$ It is reasonable to assume that a good proportion of these contain content that can be described as literary. The intention of my research, and of this article, is to study the practices of communities that employ internet technologies in order to produce, distribute, consume and value literary products. In this article, my emphasis is on poetry communities. As is shown in Maghiel van Crevel's article in this volume, the genre of poetry, often seen as culturally marginal, continues to occupy a significant niche in PRC elite culture, with some of the most avant-garde groups making good use of

* I am grateful to Charles Laughlin for his perceptive comments as the discussant for the first draft of this paper during the IIAS workshop in October 2004.

1. Quoted from an article entitled "Wangluo wenxue" ("Web literature"), originally published (possibly under a different title) in Zhonghua dushu bao (China Reading Journal), 10 October 2001, reproduced online, URL: http://www.china.org.cn/chinese/RS/65142.htm. The reproduction does not mention the name of the article's author. "wwwmm" is the screen name of one of the participants in the 2001 debate about web literature, discussed below.

2. Information provided on the CNNIC website, URL: http://www.cnnic.net.cn/ download/2005/2005012701.pdf. Most general sources on the Chinese internet referred to in this article were traced using the resources available to members of the Chinese Internet Research Group. For more information about this group, see URL: http:/groups.yahoo.com/ group/chineseinternetresearch/. 
websites to disseminate and discuss their work and ideas. However, poetry (both modern and classical) also continues to have a more popular appeal among young educated urbanites who gather in virtual communities as part of their lifestyle, without displaying any obvious interest in being avant-garde. It is the latter type of community that I intend to discuss in this article.

The article begins by providing a brief general overview of the current state of research about the Chinese internet. I take issue with the dominant tendency of English-language research to focus almost exclusively on questions of censorship. By foregrounding censorship and by highlighting what does not appear on the Chinese internet, attention is taken away from what does appear. For research on contemporary Chinese web literature this exclusive focus on censorship issues is unnecessary as censorship is a fact of life for Chinese writers and it does not make their work less valuable or interesting.

The article then looks at the development of "web literature" (wangluo wenxue) in China, briefly outlining the meaning of the term and the content of a protracted debate about it that took place in 2001. The debate illustrates the limited extent to which web literature is able to distinguish itself from conventionally published literature. Paradoxically, this has led to "web literature" becoming a recognized genre within print culture.

In the remainder of the article, I compare a PRC online poetry community with a similar community based in the United States. The comparison further emphasizes the limited distinctions between online and printed literature. It also confirms that, as many have begun to suspect, the supposed "globalness" of internet technology does not remove clear cultural differences.

\section{Research on the PRC Internet}

The CNNIC statistics mentioned above estimated the number of Chinese internet users at 94,000,000. As is well-known (and as is the practice in some other countries) these users do not have access to the world-wide web in its entirety, as the content of non-PRC sites is continuously monitored, filtered and, if deemed necessary, blocked. ${ }^{3}$ Perhaps because of the world-wide web's reputation of being an exceptionally permissive and uncontrollable space, most researchers of the Chinese internet so far seem to be predominantly interested in methods and technologies of control and censorship, that is, in what does not appear on the Chinese web, rather than what does. If initially China watchers were optimistic that the advent of the internet in China would promote freedom of speech and create niches for free thinkers

3. For an ongoing analysis of web content filtering in China and other countries see Jonathan Zittrain and Benjamin Edelman, "Empirical analysis of internet filtering in China," URL: http://cyber.law.harvard.edu/filtering/china/. 
to express their opinions, recent research seems to deny these expectations, demonstrating instead the effectiveness of state control of the internet in China. ${ }^{4}$ Among the 138 items on Randy Kluver's "Bibliography on the internet in China," studies of the Chinese internet, the vast majority deal with issues of state control versus civil liberties, with e-commerce and economic aspects the second most popular topic. References to research on cultural production on the Chinese internet are almost absent, nor can they easily be found elsewhere. A notable (and very recent) exception is Michael Day's annotated archive of avant-garde poetry websites that is part of the "Digital archive for Chinese studies (Leiden Division)." That project, however, also appears to be largely motivated by the fear that government repression will cause websites to disappear without warning: it is mainly an archive of dissident voices. That such disappearances can be immediate and extensive became clear to me on 20 September 2004 when I tried to access some of the tens of thousands of personal web pages (including 2,372 pages classed as "literature" and 25,699 pages classed as "personal manifestos" (geren xuanyan) hosted by the Chinese commercial ISP 533.net. They had become inaccessible. An announcement by the ISP explained that it had ceased its free web hosting service with immediate effect because of "problems with the contents of a small minority of the pages" and that it would henceforth only provide web space for paying customers providing full proof of identity.?

Following this, similar announcements began to appear on the websites of many Chinese ISPs, discussion forums and chatrooms. The government policy of making service providers, forum moderators and chatroom operators legally responsible for any "inappropriate content" appearing on their sites has obviously led to extensive self-regulation. The demand for users to provide full proof of identity acts as a deterrent to those possibly planning to post or host (politically) subversive content. Service providers, moderators and operators appear willing to co-operate with the authorities in this way in order to keep their sites up and running. In the context of this volume, this is one example of how the state in contemporary China continues to exercise control over culture, especially popular culture, by appealing to cultural

4. For examples of this approach, see for instance Jeroen de Kloet, "Digitisation and its Asian discontents: the internet, politics and hacking in China and Indonesia," First Monday, Vol. 7, No. 9 (2002), URL: http://firstmonday.org/issues/issue7_9/kloet/index.html and Lokman Tsui, "Big Mama is watching you: internet control and the Chinese government" (Leiden: Unpublished MA thesis, 2001; downloadable from URL: http://www.lokman.nu/ thesis/).

5. This list is available to members of the Chinese Internet Research Group mentioned above. My comments here are based on a visit to the (continuously expanding) list in September 2004

6. URL: http://www.sino.uni-heidelberg.de/dachs/leiden/poetry/index.html.

7. The URL of the announcement, being the page that would appear regardless which personal web page one was trying to access, was (and perhaps still is) http://ads.533.net/ gonggao/. 
brokers' interest in maintaining a stable marketplace for their enterprises. ${ }^{8}$

\section{Web Literature: Production-Oriented Analysis}

Although the preference for censorship-oriented research is understandable, there are good reasons to argue for the viability of a more production-oriented approach, that is, an approach that looks at what does appear in Chinese web space. Foremost among those reasons is the fact that all Chinese literature of all dynasties and periods has been produced under conditions of state censorship and this has never prevented scholars and critics from taking it serious as literary work, nor has it prevented Chinese writers from writing and readers from reading. Censorship of the internet does not necessarily confront Chinese writers and readers with an unfamiliar situation. Censorship is the norm, rather than the exception.

A second (related) reason is that censors and their practices can and should be studied as part of literary practice as a whole, whether in print culture or in cyber culture. There is no reason to ignore censorship but there is similarly no reason to overemphasize it or isolate it from the practices of other agents within the literary field.

Thirdly, the particular type of censorship practised in China is, for better or for worse, one of the things that make contemporary Chinese web literature different from that of other countries (cultures, language communities). This would support the suggestion that there is such a thing as "PRC web culture" despite the fact that the world-wide web is supposed to work against such nation-based distinctions. ${ }^{9}$

Finally, content analysis of literary websites is important because it aids our understanding of how internet technologies, as distinct from print culture technologies, are challenging familiar concepts of literature, not just in China but everywhere in the world. It is this final point that reverberated most strongly during a lively debate about web literature on the Chinese internet in 2001.

\section{The PRC Web Literature Debate}

In as far as I can claim to have an overview of the large amount of web space devoted to the debate about web literature, it began on one of the discussion forums (luntan), sometimes referred to as "bulletin boards"

8. It might be mentioned in passing that the techniques used by the Chinese government here are not new. Similar policies, based on mutual interest of government and ISPs, were arrived at in Western countries in order to suppress illegal content such as child pornography or terrorist manuals. The difference is of course that the Chinese government's definition of what constitutes "inappropriate content" is much wider.

9. Here the formulation of my argument is indebted to Jeroen de Kloet's research cited above. 
or $\mathrm{BBS}^{10}$ ) of the popular Shanghai-based website "Rongshu xia" ("Under the banyan tree") (URL: http://www.rongshu.com or http:// www.rongshuxia.com). ${ }^{11}$ The debate was sparked by a short post (tiezi) to the forum by the author Chen Cun, known to some as the "father of Chinese web literature," presumably because he was the first well-known contemporary author to switch to the new medium. ${ }^{12}$ I have been unable to retrace the original post, but its content has been copied in many places. It reads as follows:

I go online and visit Under the Banyan Tree because I want to see what web literature is really like. I have high hopes for it. But web literature these days is starting to make me reconsider. If the highest achievement of web literature is to publish traditional books offline, if that is what qualifies you as a writer and allows you to brag, then is there still a web literature? Its freedom, its randomness and its non-utilitarian nature have already been polluted. Although I understand these changes, it is still not what I hope to see. Web literature is already past its prime. What Laozi called the period of utter innocence [chizi zhi xin] has vanished too quickly. ${ }^{13}$

Chen Cun, who later withdrew from the management of "Under the banyan tree," a site which he had founded and funded, provided with this post an (in my view) accurate assessment of the position of web literature within the Chinese book market. In 2001, and probably still nowadays, it was the case that the main measure of success for a web literature author was to have his or her works appear in print. "Under the banyan tree" itself played a major part in developing these practices, as it published regular book collections of its best online works and secured generous funding from the German Bertelsmann Book Club who used the site to enter the Chinese (printed) book market. It is understandable that someone like Chen Cun, who probably saw himself as a representative of a literary avant-garde, was attracted by the possibilities that HTML writing offers for literary experimentation, ideally leading to novel ways of writing making full use of the characteristics of hypertext and hypermedia. Such writing did indeed not or hardly develop on the Chinese internet. The bulk of web literature, including much online writing that presents itself as new or shocking, is plain (or "linear") text rather than ("non-linear") hypertext. ${ }^{14}$

10. In Western cyber-circles, the term "BBS" (bulletin board system) is considered somewhat outdated, referring as it does to the text-only interactive systems of the 1980s and 1990s. In East Asia, however, the acronym is still popular and used to refer to both text-only and multimedia online forums. Cf. the article "Bulletin board systems" on Wikipedia, URL: http://en.wikipedia.org/wiki/Bulletin_board_system.

11. For a partial content analysis of this website, see Michel Hockx, "Links with the past: mainland China's online literary communities and their antecedents," Journal of Contemporary China, Vol. 13, No. 38 (2004), pp. 105-127.

12. Chen Cun's status as an important contemporary author is confirmed by the inclusion of one of his stories in Howard Goldblatt (ed.), Chairman Mao Would Not Be Amused (New York: Grove Press, 1995).

13. Quoted from the article entitled "Web literature," see n. 1.

14. This is true, for instance, of the "happening" avant-garde website called "Shi jianghu" ("Poetry vagabonds"), which consists entirely of poems that adhere to the print culture format, despite their often highly unconventional content. (Indeed, the group also publishes 
The crossing-over of web literature authors into print culture led, however, to an unusual phenomenon which continues until the present day. Within print culture, "web literature" has become a genre of its own. When I visited Beijing in 2002, I was struck by the fact that the literature sections of all major bookshops had shelves devoted to "web literature" just as they had shelves devoted to, say, "Chinese poetry" or "foreign fiction." The category also appears as a genre category on some online Chinese bookshops. In short, for a web author (xieshou) to become successful in print culture there is an additional hurdle to overcome: even if one does manage to publish one's work in print it might still carry a generic label that distinguishes it from "real" literature. On the other hand, for web authors to have this kind of entry point into print culture at all is convenient and valuable. As Howard Becker points out in an article about English-language hypertext fiction, the challenges faced by American web authors are much greater. ${ }^{15}$ I return to this comparison below.

Many of the thousands who responded to Chen Cun's post after it was first published disagreed with his pessimism. However the most frequently seen response, documented in online articles and in newspapers into which the debate spilled over by October 2001, was that the internet was after all only a medium (zaiti) for literature. Those who held this view argued that literature was literature no matter how it was distributed and that web literature, rather than being on the way out, was to have a glorious future. Although the enthusiasm for web literature does seem to have diminished since 2001, the sheer number of literary works produced for the various online forums on a daily basis is still staggering. ${ }^{16}$

Below, I take a closer look at the practices of a typical Chinese literary website, making a straightforward comparison with a similar American website. Despite the continued adherence to the print culture format, the actual practices of the Chinese website occasionally diverge from the print culture paradigm, especially in the realm of criticism and valuation.

\section{Online Poetry Communities}

The following sections briefly describe the practices of two online literary communities, one hosted on a server located in the United States

\footnotetext{
footnote continued

a normal printed journal.) In September 2004, the site was no longer accessible at the old URL (http://www.wenxue2000.com - this instead linked, ironically, to the text of a poem by Li Bai). Alternative URLs were available, leading to a collection of old work (http:// sh.netsh.com/bbs/3307/) and to a new discussion forum (http://my.clubhi.com/bbs/661502/). In December 2004 the old site was accessible again. At the time of writing (March 2005), it has once more disappeared, but the other two URLs mentioned above remain valid. The translation "poetry vagabonds" for shi jianghu was suggested to me by Maghiel van Crevel.

15. Howard S. Becker, "A new art form: hypertext fiction," URL: http:// www.soc.ucsb.edu/faculty/hbecker/lisbon.html.

16. For an overview of related articles see "2001: Qingsuan wangluo wenxue" ("2001: liquidating web literature"), URL: http://www.booker.com.cn/gb/paper253/1/.
} 
and using the English language (http://www.everypoet.com) and the other hosted on a server in the People's Republic of China and using the Chinese language (http://www.chinapoet.net). Both communities boast a large membership,${ }^{17}$ have well-designed websites and apparently a solid financial basis, gained from advertising, donations or the sale of web hosting services. They are independent domains and therefore different from the smaller communities that one finds on portals such as Yahoo. Both sites are dedicated to the genre of poetry, usually a marginal and elitist literary genre, which however seems to enjoy a remarkable popularity online.

The description below is in the form of a straightforward comparison between the US site and the PRC site. It points out where practices are identical or similar, and where they diverge as a result of cultural factors. I look at practices surrounding the production and distribution of poems as well as practices of valuation ("symbolic production"18). Following the example set in Howard Becker's book on "art worlds," into account all the skills and tools that are needed to bring an online poem into being. I also refer to a more recent essay by Becker about "hypertext fiction," already mentioned above. In that article, Becker argues that hypertext fiction, being non-linear writing requiring special software to create, special distributors to sell and special reading strategies to enjoy, is a truly new art form in the sociological sense. The world of printed literature has no way of accommodating it within the existing forms of organization and co-operation between its agents. As mentioned above, such innovative forms of online literature have not yet emerged in the PRC. Similarly, the practices described below are only partially innovative in comparison to those of offline publishing.

\section{Hardware and Software}

The basic material condition for the authors of online poetry is to have a computer with access to the internet. For most people in the United States and for increasing numbers of people in the urban areas of China,

17. When I visited the sites in May 2004, over 15,000 members were claimed to subscribe to the forums on the Chinese site; over 18,000 members were claimed to subscribe to the main forum (the "Poetry free for all") of the US site. When I visited both sites again on 20 September 2004 both were claiming a membership of over 19,000. At the time of writing (March 2005) the American site has "over 21,000 members." The Chinese site boasts 23,267 subscribers. It has, however, temporarily stopped accepting new subscriptions. Although no reason for this is given, the appearance of a two-line slogan under the announcement ("Let us jointly establish a healthy, civilized, law-abiding poetry community. Actively suppress and eliminate bad information and lend your strength to the cleaning up of the web environment") suggests that in this case, too, state intervention has brought about stricter self-regulation.

18. I borrow my usage of this term from C.J. van Rees's model for the description of literary communities. See for instance C.J. van Rees and Jeroen Vermunt, "Event history analysis of authors' reputation: effects of critics' attention on debutantes' careers," Poetics, Vol. 23, No. 5 (1996), pp. 317-333.

19. Howard S. Becker, Art Worlds (Berkeley, Los Angeles, London: University of California Press, 1982). 
computers are affordable and internet access is cheap and convenient. Membership of the two poetry websites discussed here is free, as is publication of one's work on the site. This means that most of the cost of making this kind of literature available is incurred by those who run the website. Their position combines that of publisher and book seller in the print culture system. In the PRC case, this means that the website is also subject to censorship regulations. The front page displays, at the bottom, a state registration number and a link to the government website listing the domain registration details of the site.

The basic material conditions for hosting a website like this are server space and software. Large interactive sites that generate much server traffic, like the two sites under discussion, are generally not hosted free by internet service providers. The software needed to operate the interactive forums is also not freely available. However, compared to any kind of print culture venture, the direct costs of running sites like this is small. The American site (Figure 1) seems to derive at least part of its income from advertising in banners and pop-up windows. It also offers members the opportunity to make donations. Initially, the PRC site had very few advertisement banners. In Figure 2, a screenshot of the front page of the PRC site taken in April 2004, the only advertisement present is the one on the right-hand side in the middle, advertising a printed anthology of best works from the site itself. During later visits to the site in September and December 2004 and March 2005 I noticed an increasing number of

Figure 1: Front Page of everypoet.com

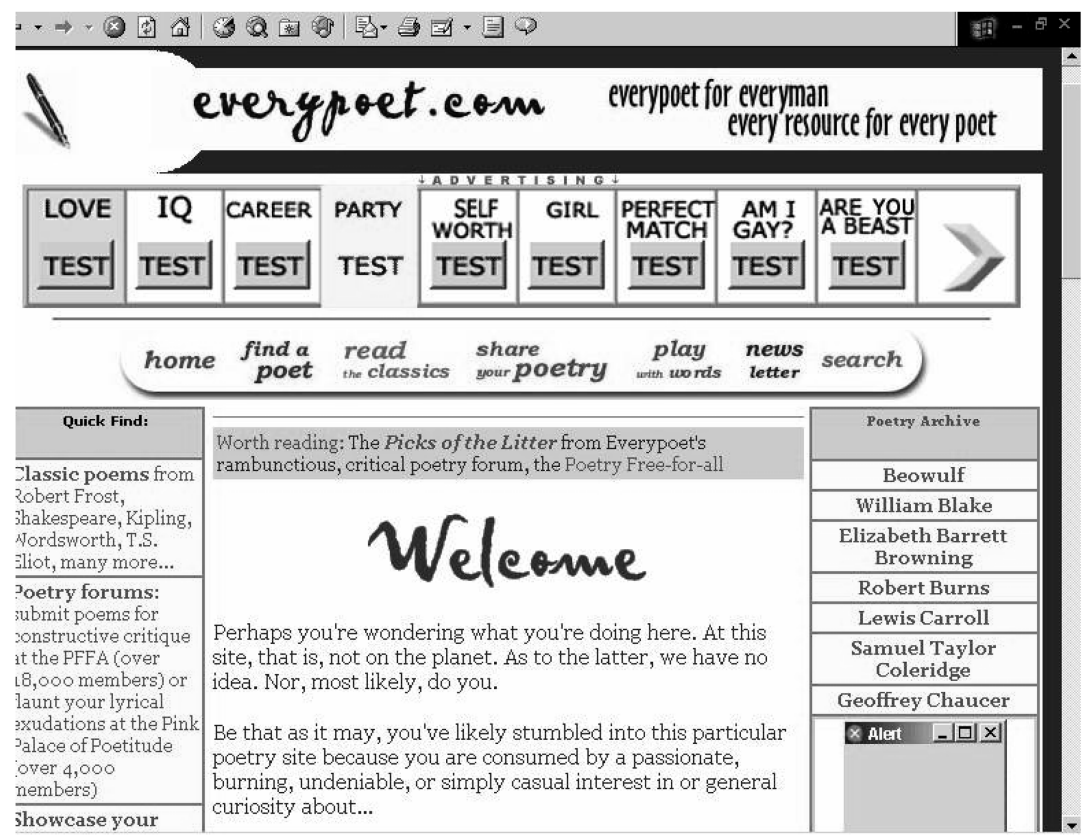


Figure 2: Front Page of www.chinapoet.net

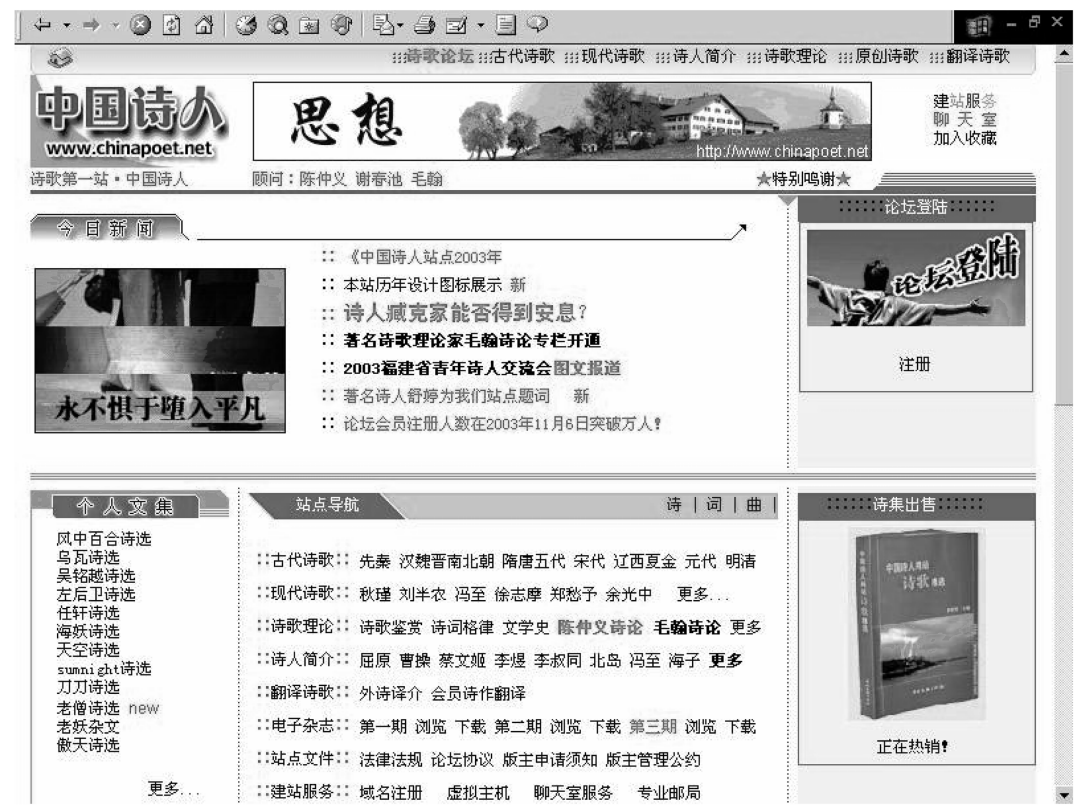

advertisements on the front page, presumably an indication of increased popularity. The PRC site also functions as a company offering paid web hosting services. It is unclear in the case of both sites to what extent the enterprises are profit-making or rather based on generous investment of time and personal funds by enthusiastic individuals.

Both sites provide copious information about famous poems and poets, this being an indication of their relative closeness to the print culture tradition. The main attractions of the sites, however, are the "poetry forums" (shige luntan). These are interactive message boards dedicated to different poetic genres, styles and themes. In China at the moment such message boards are hugely popular and literary forums such as the ones discussed here can be found on almost every portal. ${ }^{20}$ The software used by both sites appears to be identical, with the first point of entry being a page listing the various available boards and inviting the user to choose which one to read or contribute to (Figures 3 and 4). These listings also provide some statistical information about the forums, such as the number of posts and threads they contain. In both cases, the lists also provide the screen names of the moderators of each of the forums.

20. To mention just one fairly unexpected example, the website of the All China Lawyers Association (ACLA) runs a lively literary forum where lawyers can publish and discuss their own literary writing. URL: http://www.acla.org.cn/forum/postlist.php?Cat = \&Board $=2$. 
Figure 3: (Partial) List of Discussion Boards on everypoet.com

\begin{tabular}{|c|c|c|c|c|c|}
\hline & Forum & Posts & Threads & Last Post & Moderator \\
\hline \multicolumn{6}{|c|}{ Amorphous All-Purpose Anarchy } \\
\hline 8 & 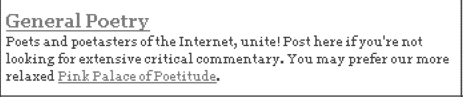 & 11905 & 2280 & $\begin{array}{l}\text { 05-25-2004 07:50 AM } \\
\text { by Artemisia }\end{array}$ & $\begin{array}{l}\frac{\text { Donney, }}{\text { garyg, Harry R, }} \\
\frac{\text { HowardMa, }}{\text { Julie Kima, }} \\
\text { Scavellia }\end{array}$ \\
\hline$Q$ & $\begin{array}{l}\text { General CBC } \\
\text { The first stop for less experienced poets desiring constructive critical } \\
\text { commentary. Please and read and respect these Groovy Guidelines } \\
\text { for Gen CarC. }\end{array}$ & 26826 & 4435 & $\begin{array}{l}\text { 05-25-2004 04:10 AM } \\
\text { by Citybreals }\end{array}$ & 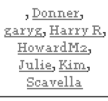 \\
\hline ○ & $\begin{array}{l}\text { Another General C\&C } \\
\text { Egad, the traffic. This new General cac forum has exactly the same } \\
\text { ains and guidelines as the other one. Take your piok! }\end{array}$ & 12875 & 1847 & $\begin{array}{l}\text { 05-25-2004 07:44 AM } \\
\text { by Mister Micawber }\end{array}$ & 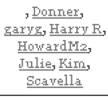 \\
\hline Q & $\begin{array}{l}\text { Scansion Mansion } \\
\text { Are your rhymes wrenched? Your ends stopped? Does your rhythm } \\
\text { have no spring? Hightail it to this stress-filled forum for metrical } \\
\text { poetry. Flease respect the House Rules. }\end{array}$ & $413^{6}$ & 466 & $\begin{array}{r}\text { 55-24-2004 04:34 FM } \\
\text { by Steph\#z }\end{array}$ & $\begin{array}{l}\text { Donnex, } \\
\text { garyz, Harry } \\
\frac{\text { HowardMa, }}{\text { Julie, Kima, }} \\
\text { Scavella }\end{array}$ \\
\hline Q & $\begin{array}{l}\text { Charon's Leaky Schooner } \\
\text { Let's get pithy: A teaching forum. } 40 \text { post minimum. READ THIS } \\
\text { FIRST! }\end{array}$ & 1932 & 229 & $\begin{array}{l}\text { 05-23-2004 08:11 PM } \text { by Lola Two } \\
\end{array}$ & 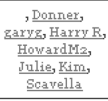 \\
\hline Q & $\begin{array}{l}\text { High Critique } \\
\text { A place for critical commentary, mainly for the more than merely } \\
\text { moderately experienced. Fark your ego outside, embrace critical } \\
\text { commentary, and read these. }\end{array}$ & 10841 & 1592 & $\begin{array}{l}\text { 05-25-2004 o8:30 AM } \\
\text { by kekala }\end{array}$ & 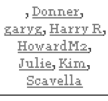 \\
\hline @ & $\begin{array}{l}\text { Merciless \& Possibly Painful Critique } \\
\text { For the more experienced, thicker-skinned, and stronger-willed. Do } \\
\text { not post here unless you have a burning desire to improve your } \\
\text { poetry. Flease yead. }\end{array}$ & 8798 & 1160 & $\begin{array}{r}\text { 05-24-2004 05:42 PM } \\
\text { by Lola Two }\end{array}$ & $\begin{array}{l}\frac{\text { Donnex, }}{\text { garyz, Harry R, }} \\
\frac{\text { HowardMa, }}{\text { Julie Kirm, }} \\
\text { Scavella }\end{array}$ \\
\hline
\end{tabular}

Figure 4: (Partial) List of Discussion Boards on www.chinapoet.net

\begin{tabular}{|c|c|c|c|c|c|c|c|}
\hline \multicolumn{6}{|c|}{ 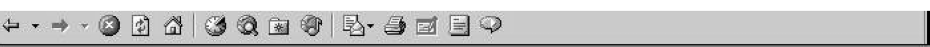 } & \multicolumn{2}{|c|}{ 果 $-a x$} \\
\hline \multicolumn{8}{|c|}{ －我登论坛 } \\
\hline 8 & $\begin{array}{l}\text { [ 论坛办公室 ] } \\
\triangleright \text { 口社区事荌的公告处, 社区用户的求助处…… }\end{array}$ & $\begin{array}{l}\text { 李可可 } \\
\text { 风如百合 } \\
\text { 管理者 }\end{array}$ & $\begin{array}{l}\text { 今日： } \\
\text { 青题： } \\
\text { 回量： }\end{array}$ & $\begin{array}{r}25 \\
1942 \\
14940\end{array}$ & 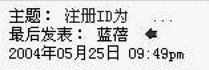 & 圆 & \\
\hline 6) & $\begin{array}{l}\text { [ 站点会议室 } \text { ] } \\
\text { 管理员讨论区 }\end{array}$ & $\begin{array}{l}\text { 李可可 } \\
\text { 管理者 }\end{array}$ & $\begin{array}{l}\text { 今日: } \\
\text { 主题： } \\
\text { 回复: }\end{array}$ & $\begin{array}{r}7 \\
538 \\
4532 \\
\end{array}$ & $\begin{array}{l}\text { 最后发表：一剑 } \\
\text { 2004年05月25日 } 10: 28 \mathrm{pm}\end{array}$ & 圆 & \\
\hline (1) & $\begin{array}{l}\text { [ 论坛诗歌精华区 ] } \\
\text { D论坛的优秀诗歌, 年度选刊和网刊的备选。 }\end{array}$ & 管理者 & $\begin{array}{l}\text { 今日: } \\
\text { 今日䞨： } \\
\text { 回复： }\end{array}$ & $\begin{array}{r}0 \\
1118 \\
7525\end{array}$ & $\begin{array}{l}\text { 主题：公告：短诗比赛 } \\
\text { 最后发表：一剑 } \\
\text { 2004年05月25日 } 08: 31 \text { am }\end{array}$ & 圆 & \\
\hline \multicolumn{8}{|c|}{ = 些取访坛 } \\
\hline 9 & 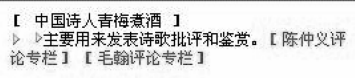 & $\begin{array}{l}\text { 刘水 } \\
\text { 吴铭越 }\end{array}$ & $\begin{array}{l}\text { 今日: } \\
\text { 主题： } \\
\text { 回量： }\end{array}$ & $\begin{array}{r}12 \\
1392 \\
7189\end{array}$ & $\begin{array}{l}\text { 主题：[原创]请诸位续贴 } \\
\text { 最后发表：将进酒 } \\
\text { 2004年05月25日 } 09: 28 \mathrm{pm}\end{array}$ & 圆 & \\
\hline$\theta$ & 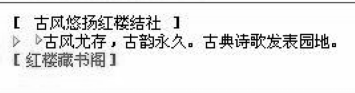 & $\begin{array}{l}\text { 田牧 } \\
\text { 歌牙人生 } \\
\text { 月白风清 } \\
\text { More... }\end{array}$ & $\begin{array}{l}\text { 今日: } \\
\text { 主题： } \\
\text { 回星: }\end{array}$ & $\begin{array}{r}142 \\
13964 \\
59877\end{array}$ & $\begin{array}{l}\text { 主题：独寂 } \\
\text { 最后发表：一还 } \\
\text { 2004年05月25日 } 10: 11 \mathrm{pm}\end{array}$ & 圆 & \\
\hline 8 & $\begin{array}{l}\text { [ 中国诗人一百单八将 ] } \\
\text { 道。 }\end{array}$ & $\begin{array}{l}\text { 吴辂埖 } \\
\text { 任轩 } \\
\text { 李三林 } \\
\text { More... }\end{array}$ & $\begin{array}{l}\text { 今日: } \\
\text { 主题： } \\
\text { 回复： }\end{array}$ & $\begin{array}{r}108 \\
16903 \\
65011\end{array}$ & 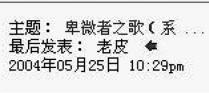 & 國 & \\
\hline 8 & $\begin{array}{l}\text { [ 先锋一派大闹天富 ] } \\
\text { 新形式, 新体验诗歌的尝试。 }\end{array}$ & $\begin{array}{l}\text { 评论者 } \\
\text { 佟声 } \\
\text { sumni ght } \\
\text { More.... }\end{array}$ & $\begin{array}{l}\text { 今日: } \\
\text { 主题： } \\
\text { 回量： }\end{array}$ & $\begin{array}{r}82 \\
7229 \\
35093\end{array}$ & $\begin{array}{l}\text { 主题：〉相遇和离别是 } \\
\text { 最后发表：傲天 } \\
\text { 2004年 } 05 \text { 月 } 25 \text { 日 } 10: 26 \mathrm{pm}\end{array}$ & 圆 & \\
\hline Q & 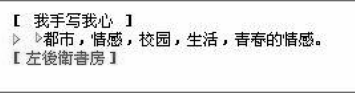 & $\begin{array}{l}\text { 天堂马匹 } \\
\text { 光头子青 } \\
\text { 月牙儿 } \\
\text { More... }\end{array}$ & $\begin{array}{l}\text { 今日: } \\
\text { 主题： } \\
\text { 回㔭: }\end{array}$ & $\begin{array}{r}230 \\
19919 \\
101202\end{array}$ & $\begin{array}{l}\text { 主题：[原创]想器, 你, } \\
\text { 最后发表：山野成 } \\
\text { 2004年05月25日 } 10: 25 \mathrm{pm}\end{array}$ & & \\
\hline
\end{tabular}


Agents

The moderators are the key agents involved in the running of this kind of online poetry forum. Combining the roles of editors and censors in print culture, they decide which posts are and which are not included but they do so (at least in the forums discussed here) after the original post has been submitted. ${ }^{21}$ In other words the moderators' main task is to screen submissions and to ensure that their content is suitable and appropriate for the forum to which they have been sent. The content of this task might vary from removing obscene or abusive messages to moving a poem to another forum where it more appropriately belongs. In the case of the Chinese site, the moderators are also responsible for ensuring that submissions do not violate government censorship regulations. ${ }^{22}$ As is the case in most internet communities, the moderators are themselves regular contributors or visitors to the site. It is unlikely that they receive more than token remuneration for their efforts. This is consistent with Becker's model of art worlds: if one wants to do things within an art world that are unconventional (such as publish online rather than in print) one must be prepared to do a lot of the work oneself, since other agents within the community might not be willing (or be trained) to provide the assistance you need.

The key agents in keeping these sites alive are of course the members contributing to the forums, either by submitting their own work or by commenting on other work posted. As mentioned before, contributions to the forums are represented as threads - as a series of individual posts on one topic - normally a poem submitted by one of the members, who, by doing so, starts a new thread. A typical forum on the US site (Figure 5) shows the title of the post/poem, the screen name of the author, the number of replies to the original post, the number of times the thread has been visited, the screen name of the last person contributing to the thread and the date and time when that last contribution was made. Various symbols on the left-hand side indicate various aspects of the status of the thread. For instance, the yellow folder symbol turns into a symbol of a flaming folder if the thread is "hot," meaning it has been responded to or visited more than a certain number of times.

21. For a more detailed discussion of the various control mechanisms of online discussion forums in China, see Wenzhao Tao, "Censorship and protest: the regulation of BBS in China people daily," First Monday, Vol. 6, No. 1 (2001), URL: http://www.firstmonday.dk/issues/ issue6 1/tao/index.html.

22. It is likely that especially the Chinese site also screens submissions with automatic filters to remove posts containing certain words or terms that are deemed unacceptable. It has recently been suggested that all Chinese messenger services, chatrooms and message boards are forced to operate filters based on a single list of "forbidden" words put together by the authorities. This list was retrieved by Chinese hackers and reproduced in full on various websites. (See Xiao Qiang, "The words you never see in Chinese cyberspace," China Digital News, 30 August 2004, URL: http://journalism.berkeley.edu/projects/chinadn/en/archives/ 002885.html. ) However, I have certainly seen some of the "forbidden" words on message boards; following the publication of the list, others have reported successfully using them in Chinese cyberspace. It is more likely that the list (with entries ranging from "democracy" to "masturbation") only applies to the messaging software (QQ) in which it was found, or that the report was a hoax. 
Figure 5: List of Threads on a Discussion Board on everypoet.com

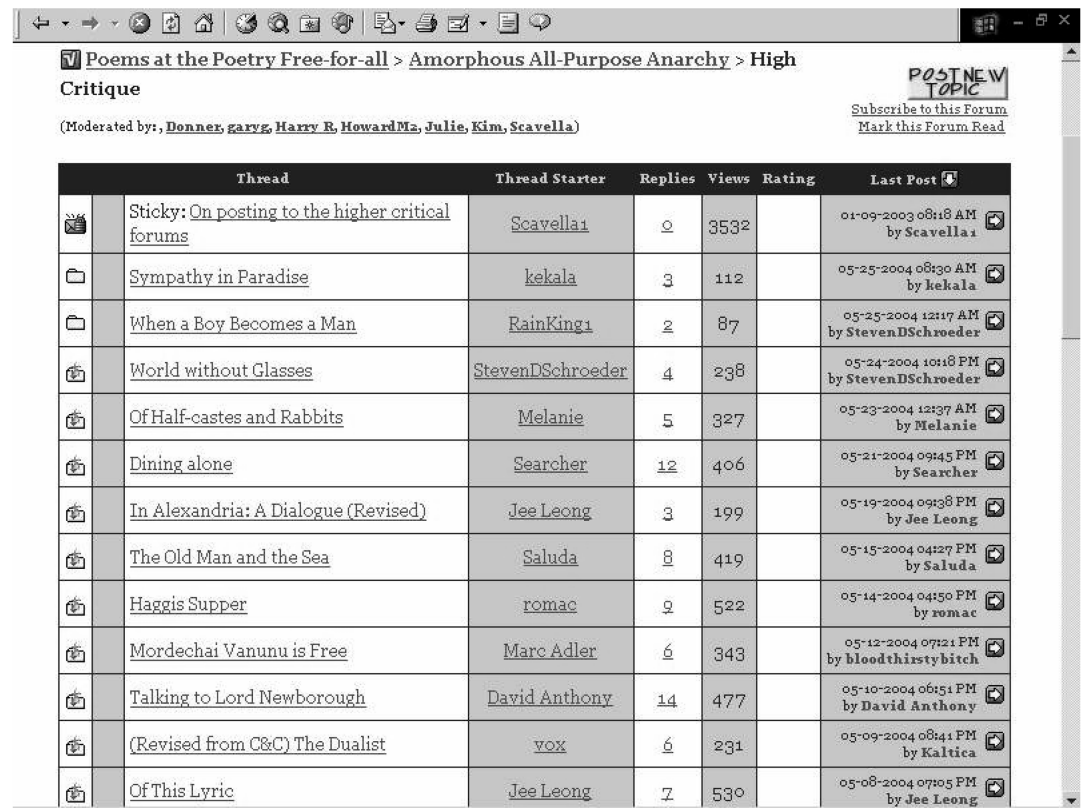

Figure 6: List of Threads on a Discussion Board on www.chinapoet.net

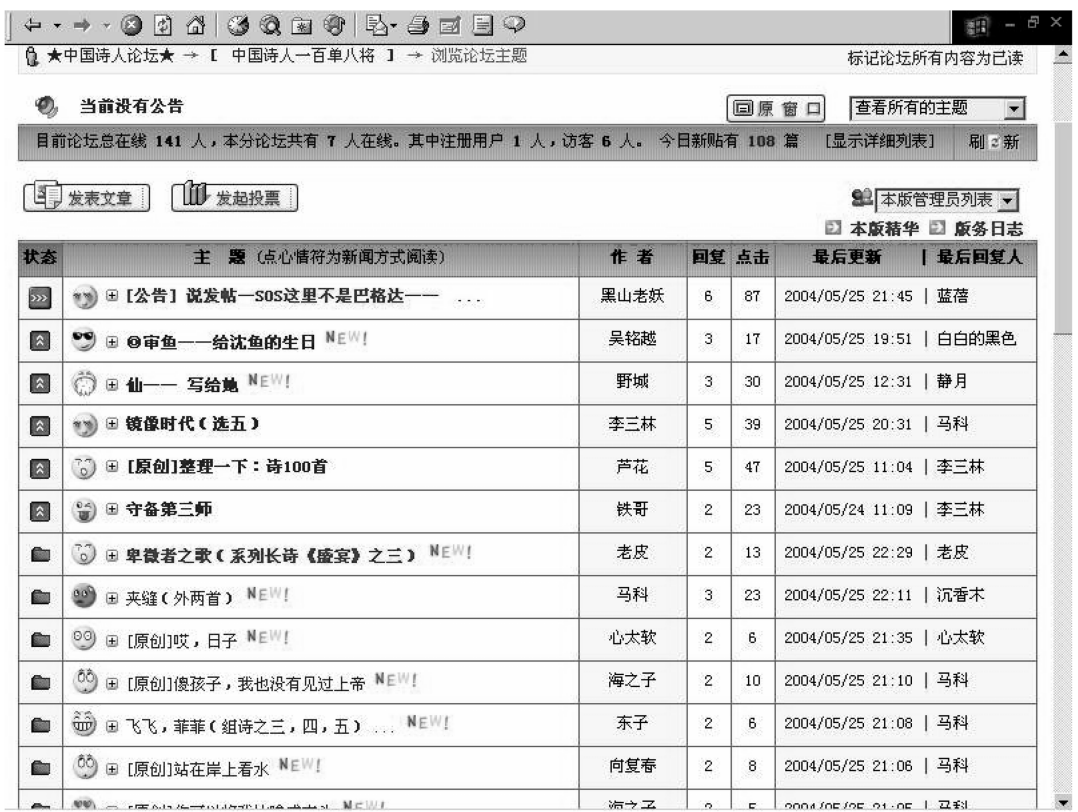


A typical forum on the PRC site (Figure 6) looks much the same. Apart from some additional symbols (which I am still looking to understand completely), the same information is provided about the various threads. As the word "thread" itself indicates, the poems submitted and the responses by other users are organized in a linear fashion, in chronological order. In other words, the threads themselves are not hypertexts. Nevertheless, the possibility of direct interaction between poet and reader/critic is unusual when compared to print culture. This is discussed in more detail below.

\section{Symbolic Production}

The main attraction for poets of publishing their poems on a website like this, rather than in a smaller writers' discussion group or on their own personal website, is the opportunity to expose their work to, obtain feedback from and get in touch with a community of poetically minded individuals. Since "being published" is the easiest thing in the world on the internet, at least part of the attraction of these websites has to be the idea of belonging to a community and obtaining some sort of recognition. Interestingly, though, a poll asking members to indicate their main motivation for writing poetry, carried out by the US site (Figure 7), shows that "emotional catharsis" was considered by a majority to be their main drive. It should be noted, though, that the answers "to get published" or

Figure 7: “Why do you write poetry?" (from everypoet.com)

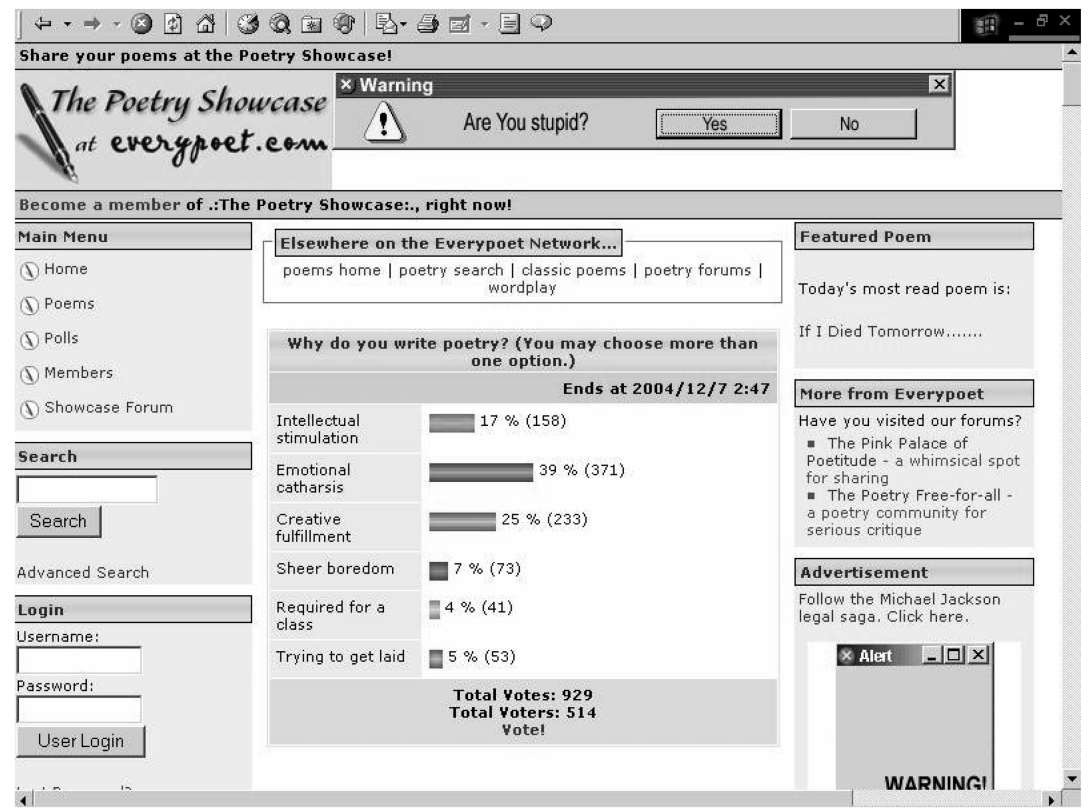


"to belong to a community" were not given as possible options to respondents.

Unlike most print culture communities, symbolic production in these online communities is not carried out by specialized critics but by other authors (that is, members who themselves are contributing poetry to the site), presumably because it is difficult to find specialist critics willing (or able) to take on the task. Moreover, it is normal for authors to respond directly to comments on their work, which is a new function not available in print culture. The moderators of both sites (themselves also authors and contributors) play a crucial role in attributing recognition to members' works as they decide which posts or threads are selected for inclusion in regularly published anthologies (the US $\operatorname{site}^{23}$ ) or on a special board for the best of Chinapoet. This special board in turn provides material for the editors of the two web journals (wangkan) which Chinapoet strives to publish each month, one for modern poetry and one for classical poetry. ${ }^{24}$

The web journals are edited by a small group of moderators. The contents of the journals represent only a very small part of what is contributed to the site every month. The works (poems and essays about poetry) are presented on nicely designed web pages that do not have any interactive functions, that is, they can only be read and not commented on. The web journals are not unlike printed literary magazines of the kind that appeared in China in the 1920s when new printing technologies (and New Literature) were spreading. Those magazines, too, were low-cost ventures produced by small editorial collectives participating in a literary economy that valued swift and frequent production. Furthermore, the fact that editors select a tiny proportion of work submitted to them for inclusion into a journal is also not dissimilar from the editing process of a print culture journal. The main difference, however, is that in this case all contributions get published on the site first. To have one's work included in the site's web journal is probably the highest possible form of symbolic recognition that a contributor to Chinapoet can obtain within the site itself. Other literary websites in China have web journals as well and some of them are important mouthpieces for groups that have little access to, or interest in, official print culture. On the other hand, the format of the web journals is so devoid of interactive characteristics that they can also be seen as possible stepping stones into print culture. They could simply be (and presumably sometimes are) printed off and enter the offline literary world. Unlike the world of hypertext fiction discussed by Howard Becker, the world of online Chinese poetry on the whole displays

23. Information based on my April 2004 visit to the US site. During a visit in December 2004, I failed to detect references to such anthologies. During that visit the US site did have special boards in which some of its best contributions were preserved. Members were not allowed to add work to those boards, but were allowed to submit comments as usual.

24. Recent issues of the site's web journals (starting from the August 2004 issue) are accessible through links on the page listing the discussion forums: http://www.chinapoet.net/ cgi-bin/leobbs.cgi. I have been unable to find an index page of all issues published so far. It is possible that publication did not start until August 2004. 
no intention to break away from print culture paradigms, making the boundaries between the two much more fluid.

The web journal phenomenon is worthy of further separate investigation. A useful question to ask would be whether or not the editors' selection of works for inclusion in the web journals is influenced by the valuation of those same works by contributors to the discussion forums. It is likely that a certain amount of recognition derives from the statistics indicating how often a poem has been read and commented on. I noticed that, as I was browsing the forums, I was generally inclined to click on threads with high statistics, assuming that they would be more interesting or controversial than others. Naturally these numbers can be manipulated by the author, if he or she simply keeps going back to the thread to add new posts. The US site has a rule against such behaviour and moderators are authorized to delete any posts from authors other than those directly responding to critical suggestions from other posters. Moreover, it also asks of each member not to post more than one poem per forum per day, and to post three responses to other people's work for each original poem posted. Clearly, the US site values the "mutual aid" aspect of the site and is wary of becoming merely a showcase of aspiring poets' work or (the other extreme) a glorified chat room. No such rules can be found on the PRC site, ${ }^{25}$ which does, however, as mentioned above, have strict rules for the content of posts, based on government censorship regulations.

\section{Censorship}

Figure 8 shows the rules for submission to Chinapoet (as downloaded in April 2004). There are two main parts. One part lists all the content that is not allowed on the site, including "writings violating the PRC constitution, the policy of reform and opening up and the four cardinal principles," "writings attacking the PRC government, the Chinese Communist Party and its leaders," "writings propagating violence, superstition and licentiousness," "writings exposing state secrets" and (lastly) "all other content forbidden by law." The second main part lists all types of screen names that members are not allowed to use, including "names, stage names and pseudonyms of Party and government leaders or other celebrities" and "names of state institutions and other institutions." Most importantly, however, and mentioned three times in bright red font, the site is closed to any and all content alluding to the outlawed falun gong movement. The last line states unequivocally: "This site does not welcome falun gong. If we see one we delete one" (jian yi shan yi).

This is not just paying lip service to government campaigns. When doing research on another paper on web literature three years ago, I found that falun gong members and sympathizers were indeed using freely accessible bulletin boards to spread information about their movement

25. During my last visit to the PRC site, in March 2005, a notice had appeared informing users that no more than three posts per member per day would be allowed. There was however no encouragement for users to post more responses to other poems. 
Figure 8: Rules for Contributors (from www.chinapoet.net)

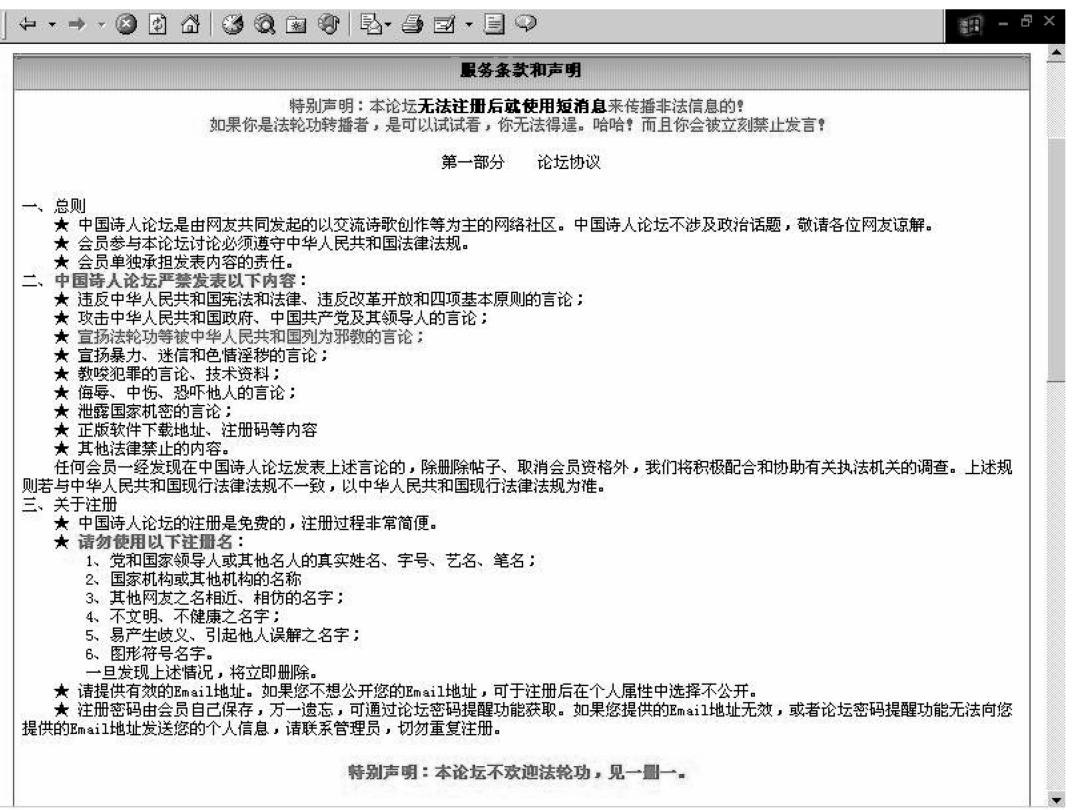

and to denounce government oppression. Failure to remove such contributions in time might lead to a website being closed down. The alternative to outspoken warnings like the one cited above would be to renounce the open character of the forums and screen every contribution before publication, a step which Chinapoet obviously is not willing or able to take, since it would place a much heavier burden on forum moderators. As shown above, there is now a tendency among Chinese ISPs and forum hosts to add membership registration to its strategies of keeping out unwanted content and avoiding legal responsibility. ${ }^{26}$

\section{Cultural Differences}

A comparison of the content of some of the threads on the two sites reveals some more cultural differences. At the moment I can only characterize these as differences between the cultures of the actual sites, although the Chinese site confirms ideas I have about the cultural specificity of modern Chinese literature and criticism as a whole. Empirical support for those ideas awaits, however, a much more comprehensive reading of these and other websites.

26. As I was making revisions for the final version of this article (in March 2005), there was an uproar among China's "netizens" about the restrictions imposed on popular discussion forums at Qinghua, Fudan and Nanjing Universities. In this case, the restrictions (suspending off-campus access and making full registration of members compulsory) appeared to have been imposed directly by the authorities, rather than being the result of self-regulation. 
Figure 9: Comments on a Poem (from everypoet.com)

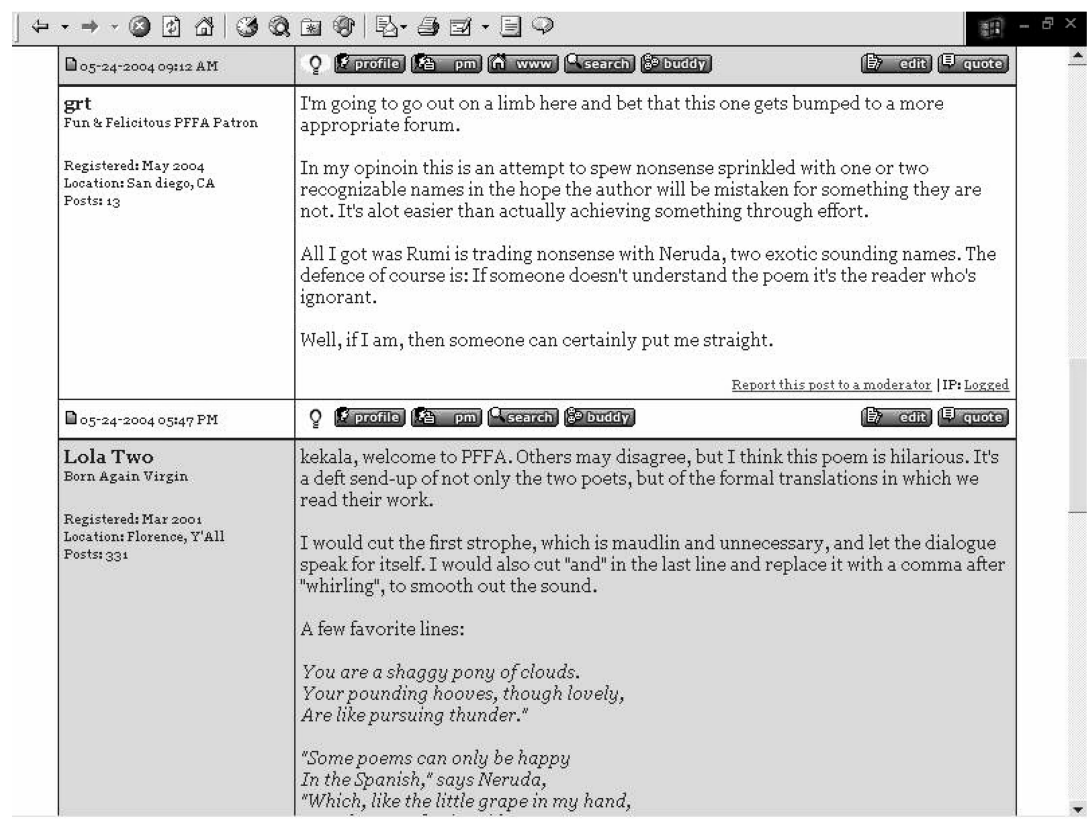

Substantial differences are noticeable in the area of symbolic production. Figure 9 shows a part of a typical thread on the US site. The discussion focuses on whether or not the poem is "good enough" to be included in this particular forum, which is meant for "more than merely moderately experienced poets" (Figure 10). Responses to poems are very specific as to which words in which lines might be changed or omitted. In general, the US site strongly propounds the notion of poetry as a craft or skill which requires considerable training and investment of time and which needs to be subjected to harsh criticism in order to be able to improve. In fact, the US forums are partly subdivided on the basis of the harshness of criticism allowed to be submitted to threads, with the most fiercely critical forum presented as the one to which only the best poets/critics should contribute.

On the PRC site, the issue of skill and discussions about the right word in the right place are much less prominent, although they do appear in the forum dedicated to those writing in the classical style, which of course has very strict prosodic rules. The feedback on poems in the modern poetry forums is much less normative, and often consists of one-liners of the type "I like this poem" or "I don't like this poem," without going into much detail. Questions of content and personality are also often debated. A typical example is shown in Figure 11, which shows two responses to a simple poem (not shown) expressing love for a woman. The first response basically dismisses the poem as romantic rubbish. The second response points out that this would be the case if the poet had been a man, 
Figure 10: Posting Guidelines, "High Critique" Forum, everypoet.com

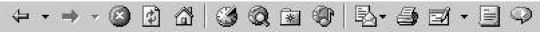

A place for critical commentary, mainly for the more than merely moderately experienced. Park your ego outside, embrace critical commentary, and, as always, comment on at least three poems for each one you post. Good luck!

Before you consider posting, please read these guidelines in full:

Welcome to the High Critique forum of the Poetry Free For All. This is where things start to get pithy, and subsequently, where the bar is set higher. As with all the forums, the Posting Guidelines are very much applicable here. So too are the High guidelines below:

1. "More than merely moderately experienced" means that, as a writer, it is assumed you know the basics of poetic knowledge. You should know common poetic terms, common forms, and what the heck clichés and abstractions are. There should be evidence from the quality of the poetry you post that you have put thought into it, that some revision has already been done, and that you are ready for and will understand the forthright, honest, and potentially harsh critique you will receive in High.

1a. If the moderators do not feel that your work indicates a fundamental knowledge of poetic basics, and that you have not, in fact, put some work and some thought into it, the moderators reserve the right to delete it, lock it, or move it to a more appropriate forum. We'd prefer it, however, if you lurked in High and figured it out for yourself. If you're not sure you're up to posting in High, post in General C\&C instead. Better safe than slapped by mods. Trust me.

2. "More than merely moderately experienced" also means that, as a critic, it is assumed you know the basics of poetic knowledge. With your comments, it should be clear that you are generally able to grasp a writer's intent and evaluate how successful the poem communicates that intent, that you have an appreciation of how sound works in poetry, and that you have a familiarity with figurative language, metric forms, and effective use of rhyme. Lastly, you should be able to tell when a revision is actually regressing rather than progressing. If you can't do that, you should hang out in General C\&C a while to get the hang of it.
\end{abstract}

Figure 11: Comments on a Poem (from www.chinapoet.net)

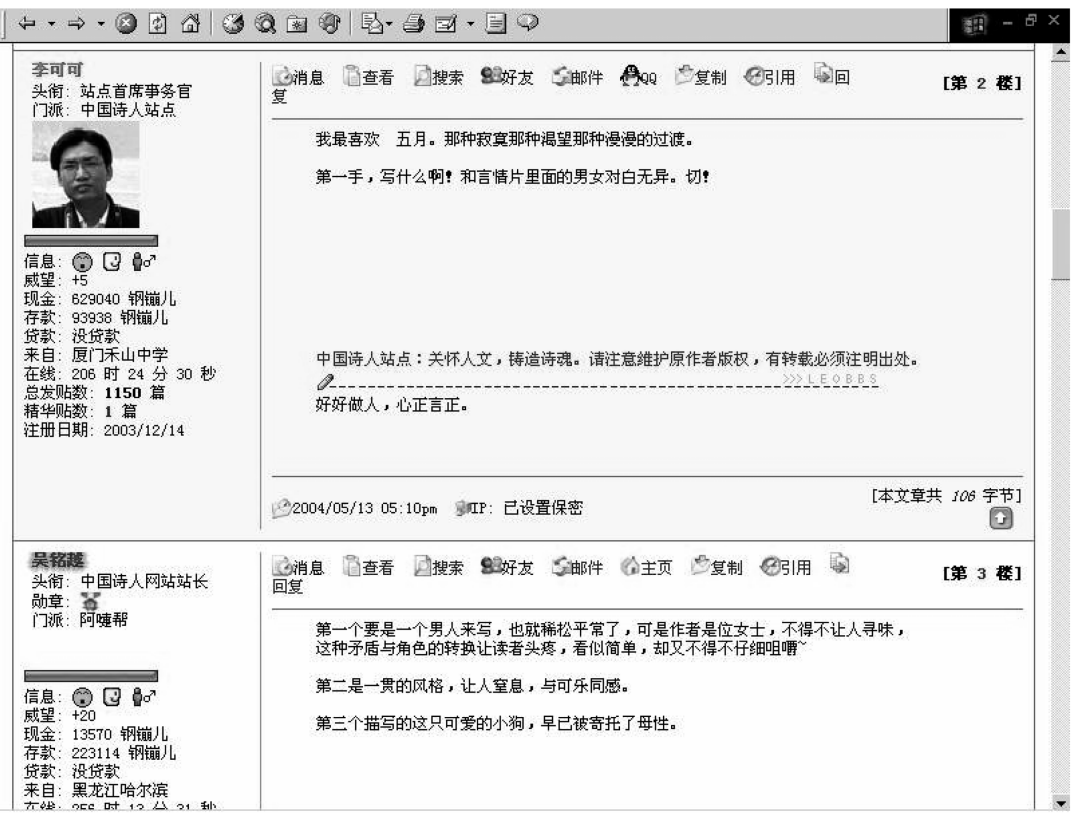


Figure 12: List of Threads, Poetry Translation Forum, www.chinapoet.net

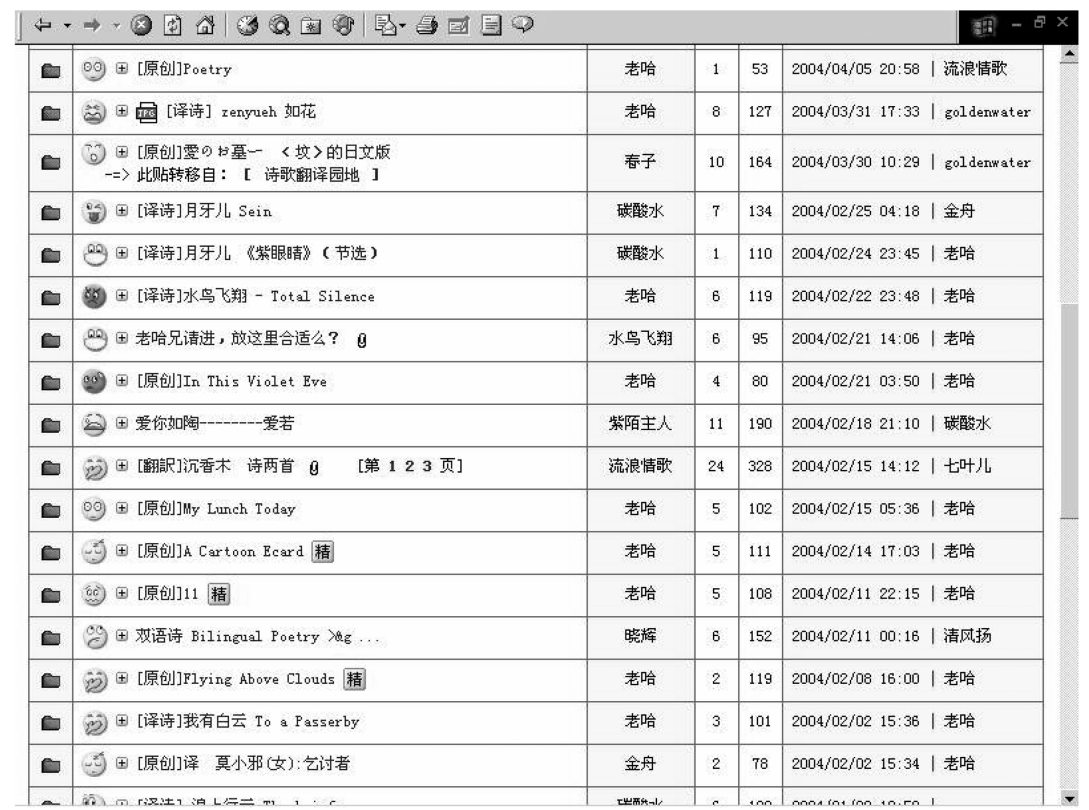

Figure 13: User Statistics for www.chinapoet.net

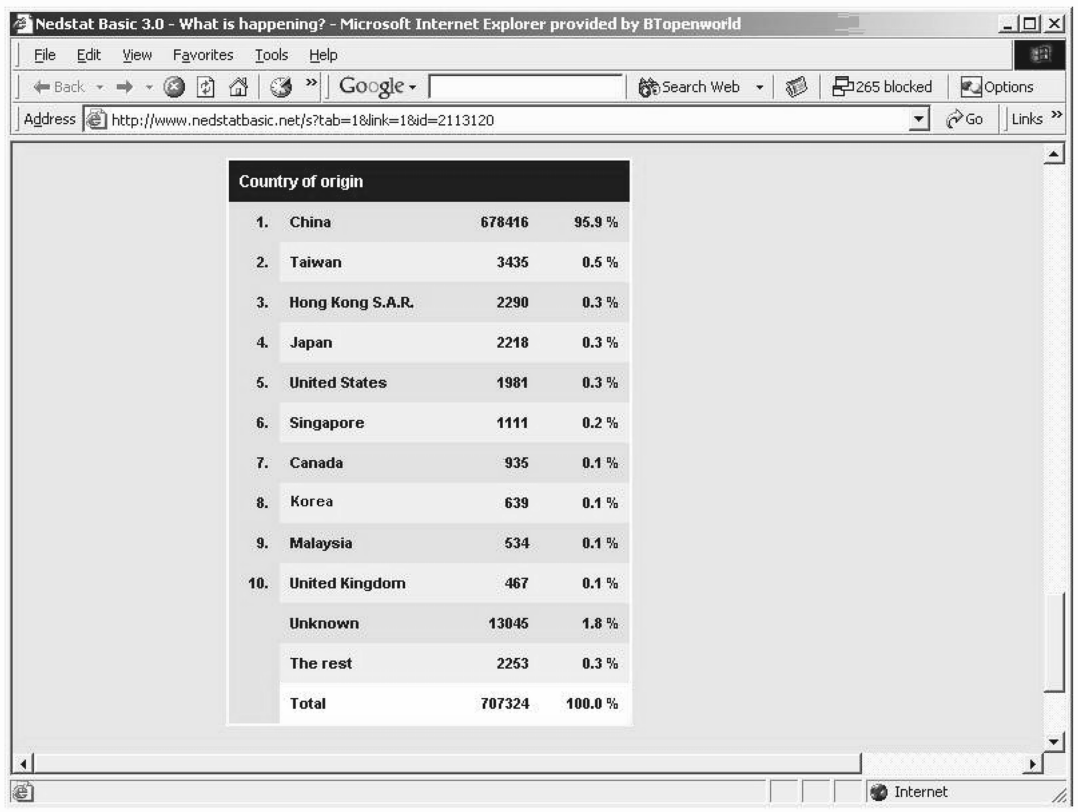


but since the poet is a woman writing about love for a woman, it is actually much more interesting and gives the reader "food for thought" because the poet creates a "contradiction" and a "role reversal."

Unlike the US site, the PRC site has a lively forum devoted to translation. Although the forum does not limit the languages used, all translations I have seen were either from or into English (Figure 12). The forum has separate "sub-forums" for translation of famous English poems into Chinese and translation of members' poems into English. These forums naturally attract much normative discussion. The inclusion of translation and the focus on English places the Chinese site firmly in the margins of the system of world literature, whereas the total neglect of translation places the American site squarely in the centre. This mirrors the situation in print culture. The fact that, according to the site statistics, 95.9 per cent of its visitors are from China, and another 1 per cent or so from Sinophone areas such as Taiwan, Hong Kong and Singapore, shows the nature of the predicament.

\section{Conclusion}

Online literature communities are, on the one hand, part of the print culture community, as are writing clubs, school newspapers or other communities in which aspiring writers practise, discuss and publish in the hope of finding recognition and perhaps one day becoming an acclaimed print culture author. At the same time, however, these communities foster direct interaction across vast geographical distances, coupled with publication for a potentially huge audience, a combination that print culture practices would find difficult to accommodate. The use of similar software and protocols in different cultural settings ensures that the practices of online communities all over the world have certain elements in common, such as their tendency to rely in part on statistics for recognition and the blurring of boundaries between specialized roles such as author, critic and reader, which are so crucial to the practices of print culture. Moreover, the nature of the online medium seems to favour, at least for the moment, the shorter genres such as poetry or the serialized story (or ongoing role-play), creating a more central position for genres that tend to be marginal in print culture. At the same time, cultural differences are observable and demonstrate that cyberspace is not the locus of any kind of transnational cultural expression.

In that respect, a final comment must be made about the relative status of both the US website and the PRC website in the context of internet studies and literary studies. In a provocative newspaper article entitled "Internet studies: what went wrong?" David Gauntlett uses the publication of the first edition of his edited collection Web.Studies ${ }^{27}$ to criticize

27. David Gauntlett (ed.), Web.Studies: Rewiring Media Studies for the Digital Age (London: Arnold, 2000). (A revised edition, edited by Gauntlett and Ross Horsley, came out with the same publisher in 2004.) 
other scholars of the internet for not keeping up with recent developments and for not taking their research beyond the level of description. Gauntlett writes:

The rise of the internet in the past three or four years means that its users know far more about sex, politics, hobbies, and shopping than ever before.

You would expect that internet scholars would be lapping all this up. It's a transformation of modern society, affecting many spheres of everyday life as well as broader social processes....

But no. Publishers are still churning out books called "Virtual something" and "Cyber something else." They might as well be called "Wow! Virtual communities!" and "Holy cow! In cyberspace, no-one knows who you are!" Even the journals are still publishing those articles which people were pulling out of the drawer in 1996. Has no-one changed the record? The internet might change politics. It might not. It's a global phenomenon. It's not really a global phenomenon. Something funny happened to a bunch of people in a chatroom. Give me a break. ${ }^{28}$

As someone interested in the relationship between internet and literature, I disagree with Gauntlett's statement. I found that what little Western scholarship on web literature exists is almost exclusively focused on the most innovative forms, especially hypertext and hypermedia. ${ }^{29}$ It is very much up-to-date with current developments, but the majority of literary production by internet users is not considered. Some scholars even present their exclusive focus on hypertext as methodological correctness, as in the following excerpt from an article discussing questions of method in analysing internet texts:

Based on the earlier discussion of the characteristics of hypertext, it is clear that the greater the opportunities of surfing provided by the text, the greater the likelihood that readers are empowered to "write" their own texts. WWW sites that remain "closeended" do not provide empowerment to readers and could thus be far less suitable as the starting point of the analysis.... These texts are limited in scope and fail to use the full potential of the WWW. ${ }^{30}$

At the same time, I found scholarship on the Chinese internet overly concerned with the issue of censorship, while rarely addressing the enthusiasm and creativity of the majority of Chinese internet users, which is so readily observable to anyone who visits Chinese websites. There is, in other words, a tendency among Western scholars to focus on the potential of the internet to bring about a transformation of society (or literature, or culture, or politics). And there is a simultaneous tendency among Western scholars of the Chinese internet to foreground censorship issues, as if to demonstrate that lack of personal freedom will always

28. David Gauntlett, "Internet studies: what went wrong?" originally published in Times Higher Education Supplement in 2000, URL: http://www.newmediastudies.com/thes.htm.

29. For instance, the authoritative website for humanities research "Voice of the shuttle" (URL: http://vos.ucsb.edu/) does not have an entry for cyber literature, neither under "cyber culture" nor under "literary theory." Both categories do have entries about hypertext.

30. Ananda Mitra and Elisia Cohen, "Analyzing the Web: directions and challenges," in Steve Jones (ed.), Doing Internet Research: Critical Issues and Methods for Examining the Net (Thousand Oaks, London, New Delhi: Sage Publications, 1999), p. 193. 
cause Chinese society (or literature, or culture, or politics) to lag behind the West when it comes to being transformative, innovative or empowering.

This article has shown that a different perspective is possible. Sure enough, there is no indication that Chinese cyber writing will radically transform Chinese society or even Chinese literature. Partly this is because the state has developed effective mechanisms to ensure that it cannot do so; partly it is because many of its practitioners lack interest in being either transformative or avant-garde or both; partly it is because literature fulfils a different function in Chinese culture. Yet although Chinese web literature is only mildly innovative, it has been the topic of intensive debate among Chinese critics and scholars of literature and it has literally made a name for itself among critics, publishers and book sellers in the larger print culture world, something that Western web literature has conspicuously failed to do. 